\title{
INTERNALIZATION OF 'KUALAT' TEACHING AS AN ATTEMPT TO PREVENT CORRUPT BEHAVIOR AMONG CIVIL SERVANTS
}

\author{
By: \\ Afnan Fuadi \\ Widyaiswara Balai Diklat Aparatur Sukamandi \\ Ministry of Marine and Fisheries \\ afnanfuadi@yahoo.co.id
}

\author{
ARTICLE INFORMATION \\ Article history: \\ Received June 20, 2017 \\ Revised Nov 15, 2017 \\ Accepted Feb 14, 2018

\section{JEL Classifications} \\ K42; D73; Z12

\section{Key Words:} \\ Kualat Teachings, \\ Internalization, \\ Javanese Wisdom, \\ Corruption, \\ Civil Servant \\ DOI: \\ 10.21532/apfj.001.18.03.01.01
}

\begin{abstract}
Corruption in Indonesia has been increasingly rampant, ranging from high-ranking state officials to lower-level civil servants. The strategic tasks mandated to civil servants have in fact provided opportunities for them to commit corruption. Based on data from Indonesian Corruption Watch (ICW), from 2013 to 2016, most corruptors work as civil servants. Based on this fact, there seems to be an alternative approach that should be more optimized, namely a cultural approach. Indonesia has many unique teachings, one of which is the Javanese philosophy of life (Javanese Wisdom). This study deals with the kualat teaching derived from the Javanese Wisdom as an attempt to prevent corruption among civil servants. This study tries to explain the noble advice in the Javanese society, particularly about kualat teaching. The researcher conducted a survey to Civil Servants to find out whether the kualat teaching still existed in the minds of civil servants. Finally, the researcher offers the idea of the need for internalization of the kualat teaching in the material content of Leadership Education and Training (Diklatpim) IV. The researcher seeks to actively participate in preventing corruption among civil servants.
\end{abstract}

\section{INTRODUCTION}

Corruption is a serious problem in Indonesia. Until now, corruption has made headline in all media, both printed and electronic. Corruption is just like a virus that continues to invade the body of this country. Almost no part of the body of this country is free from the attack of this dangerous virus. The head, hands, feet and all parts of the body have been infected with this virus. Corruption 
is committed not only by low-level of society, but also by high-level of society. One of the important organs in government, which are also very susceptible to this corruption virus, is a civil servant.

Civil servants are human resources serving as the driver of the government bureaucracy in carrying out the activities of state administration. Civil servants are tasked to carry out public services, governmental affairs, and specific development tasks. In addition, civil servants also have access to various sources of revenue and expenditures of the State. These strategic tasks eventually provide many opportunities for corruption. For example, the government officials who handle licensing and taxes have many opportunities to accept bribes paid by companies to "outsmart" regulations by simplifying the licensing process or reducing the taxes set by government.

Despite various benefits and facilities, there are still many civil servants involved in legal cases. Based on data from the Ministry of Home Affairs, there are 1,091 civil servants involved in legal cases, mostly on corruption. "In the last two years, from 2010 to 2012, the number of civil servants entangled in legal cases in all regions in Indonesia was as many as 1,091 people. The case of corruption dominated the legal cases in Indonesia, or reaching 60 percent," said Minister of Home Affairs Gumawan Fauzi at the Merdeka Palace, Jakarta, (beritasatu.com, 28/11/2012). The Indonesian Corruption Watch (ICW) recorded that from 2013 to 2016, most actors of corruption cases were civil servants and private parties. "It is likely that the sector of good and service procurement is still the main sector hijacked to gain benefits for personal or group interests,"said one of the personnel of Law and Justice Monitoring Division of ICW, Aradila Caesar, at the Office of ICW Kalibata, South Jakarta, (Tribunnews.com, 4/3/2017)

Various efforts have been made by the Government to fight against corruption.
One of them is through the establishment of Corruption Eradication Commission (or better known as KPK). As regulated in Law Number 30 of 2002, the Corruption Eradication Commission (KPK) is granted three special powers at once: pre-investigation, investigation and prosecution. According to Basaria, with these powers, throughout 2016, KPK reported 17 cases of red-handed operation. Of the 17 cases, KPK assigned 56 suspects with various profiles. In 2016, KPK also investigated 96 cases of corruption. Then, KPK investigated and prosecuted 99 people out of 77 cases (hukumonline.com 9/1/2017). In addition to curative efforts, the eradication of corruption also continues to be done through preventive efforts, either through legislation efforts, public education efforts or educational efforts by NGOs. Then all forms of corruption acts are emphasized by formulating them in the legislation.

Through these efforts, Indonesia has consistently shown an increase in its attempts to eradicate corruption in the public sector. "Indonesia's 2016 Corruption Perceptions Index (CPI) score has increased by one point, with the score of 37 out of 100 . Yet globally, Indonesia still ranks 90th out of 176 countries measured in the world. The increase in CPI score in Indonesia has not been able to compete with the neighboring countries such as Malaysia (with the score of 49), Brunei (58) and Singapore (85)," said Dadang Trisasongko, Secretary General of Transparency International Indonesia (www.ti.or.id, 25/1/2017). The Chairman of Supreme Court Hatta Ali, based on data from the Supreme Court, said that the the number of corruption cases handled in 2016 was 453 cases. Hatta further said that the corruption case this time not only involved officials but also the judicial officers. In 2016, it was noted that at least 13 judicial officers were allegedly involved in bribery, ranging from judges, clerks of court, to court staff (CNN Indonesia, Wednesday 28/12/2016). The results of research 
of Laboratory of Economics, Department of Economics, Faculty of Economics and Business, University of Gadjah Mada, also reveal that the number of corruption cases in Indonesia continues to increase. The number of corruption cases decided by the Supreme Court (MA) from 2014-2015 was as many as 803 cases and involved 967 defendants of corruption. The number increased dramatically when compared with the data in 2001-2009. At that time, the number corruption cases decided was 549 cases with 831 convicted (Liputan6. com, 7/0/2016).

Based on the above data, it can be concluded that until now corruption cases in Indonesia have not experienced a significant decline. Indonesia still has to keep working hard to fight against corruption. Despite many corruptors put in jail, the new elements involved in corruption cases continue to emerge. This indicates that the punishment imposed has not fully provided a deterrent effect. Departing from this fact, it seems that the eradication of corruption in Indonesia cannot be charged to the KPK only. It also needs other long-term supporting efforts that can touch the collective consciousness of every citizen that corruption is a bad behavior.

Of the many efforts that have been made, there is one alternative that should be more optimized, that is, cultural approach. Why using cultural approach? It is because culture, in the dynamics of society, is driven by a system of traditions. According to Soedjatmoko (1984), system of traditions consists of value system, meaning system and behavioral system that are more complete and able to stand alone, without being equipped with external systems. Culture organizes people to be able to understand how to act and to determine their attitude as they relate to others. Thus, in the case of the eradication of corruption, the cultural approach will be able to convey anti-corruption messages at the value level.
Indonesia has a lot of good and unique cultural doctrines. One of them is the Javanese philosophy of life, or called Javanese traditional wisdom. Javanese traditional wisdom is a life teaching that is used or common in Javanese society. The Javanese wisdom, which emphasizes on harmony in every dimension of life, provides a value for the existence of the universal causation law that applies to all beings that sooner or later every deed will get its consequences. Javanese society defines the bad consequences arising from bad deeds with the term "Kualat" (bad karma).

Through this paper, the author will adopt kualat teachings contained in the Javanese traditional wisdom. In addition, the author will also describe the noble advice of Javanese society that supports the existence of kualat teachings. The author will also try to find out the extent to which kualat teachings exist in the belief of the participants of the Leadership Education and Training (Diklatpim) IV of the Ministry of Marine and Fisheries. The author believes that if it is firmly held, kualat teachings will fortify a person from a variety of bad behaviors. At the last, the author will offer the idea of the internalization of kualat teachings as one of the material content in the Leadership Education and Training (Diklatpim) IV.

\section{The Entity of Kualat Teachings in Javanese Wisdom}

Most Indonesian people know and understand the term kualat. This term is very familiar in the ears of Indonesian people, especially among the people of Java. "Awas lho, hati-hati, nanti kuala!' (watch out, you'll get bad karma..." that's the warning of the parents to their children. Kualat teaching is one of the pillars of the strength of morality in the Javanese tradition. Through this teaching, one will have a fortress of consciousness within himself to stay away from bad deeds. The Javanese traditional wisdom has 3 (three) main foundations: the foundation based on the 
awareness of divinity, the foundation based on the awareness of universe, and the foundation based on the awareness of humanity. One of the Javanese traditional wisdoms which are believed and held tightly and passed down from generation to generation is the kualat teaching.

The term kualat is derived from Javanese term, which means a bad luck a person experiences as the consequence of the injustice he / she does. According to Indonesian Dictionary (KBBI), kualat /ku'a lat/ means get a disaster (for doing poorly to the parents and so on); damned; wretched, hit by curse; Kualat here means that those who do evil will get get the evil, sooner or later. Kualat is different from sin. Kualat is the misfortune or misery that a person experiences instantly in the world because of his bad deeds. Kualat also tends to apply on the relationship among humans and between human and nature. For example, Javanese society believes that kualat will befall the people who collect wealth in forbidden ways, such as stealing, robbing, corrupting, or deceiving. People who do such bad deeds will someday get disaster.

Kualat teachings are closely related to the belief in the causation (law). Causation is affected and influenced by the factor of miracle. But, it should be kept in mind that the miracle factor here is not synonymous with mysticism or occult practices. It is the belief that the real events experienced by humans are much influenced also by factors that cannot be reached by naked eye. The causation, which is identical with the kualat teachings, is not only found in Javanese society, but also in other regions in Indonesia. Causation law is also believed by Tanah Minang people, called hukum tabur tuai, such as in the story of Malin Kundang which is so popular throughout this country. It can be used as an indicator of how strong the belief of Indonesian children in the kualat taechings.

The kualat teachings existing in Javanese society are also closely related to the belief in Hinduism, known as the law of karma. The law of karma has become a reminder or warning which is greatly feared by the followers of Hindu, especially when they do not do good things in life. The law of karma is believed to apply to every being in the world. The law of karma does not recognize exceptions. It is applicable to all human beings. They can determine, if A does A, then A will get A.

The concept of kualat is also similar to laknat (curse) or azab (punishment) in the teachings of Islam. The interpreters vary in interpreting it. However, if it is associated with natural phenomena or events that afflict humans in general, it has a principle similar to that of the Javanese wisdom, which denotes the bad impact that the sinners will receive. There is a story in the hadith narrated by Imam Ahmad 4/382, Thobroni, Baihaqi, in Syu'abul Iman 6/197 which is very popular among Muslims. It is about a person named Al Qamah who got difficulty to die due to his iniquity to his mother, The Prophet SAW decided to burn his body, but it was finally canceled because the mother did not have the heart and finally forgave him. Mudatsir (1985), as quoted by Bambang Pranowo, Professor of Sociology of Religion of UIN Jakarta, considers that kualat teachings are the strength of the tradition of the Nahdhatul Ulama (NU), a mass organization of Islam, whose majority of the members come from the villages in the Java region. This concept of kualat is one part of the transformation of Javanese culture toward Islam.

Viewed from a scientific point of view, kualat and causation law are not mere coincidences. As explained in the physics theory, every action will cause a reaction, every cause will have an effect, and every effort will produce something at the proper time, without exception. There is no effect without cause, but once doing something, it will bring various effects. There are types of rice that are ready to be harvested after 90 days, but others are ready for harvest after 120 days. Of course, 
there must be some causes, such as the type and quality of seeds, fertilizers, treatments, weather, etc. The law of conservation of energy states that energy cannot be created or destroyed, it only changes from one form to another, or transferred from one object to another. This explains that the universe is created by God in balance, no excess so that it should be reduced, or no shortage so that it should be added. Everything has been prepared completely including energy in it. The amount of energy remains the same, but it changes in the shape only. Based on natural processes, water turns into steam, wood turns into embers, uranium becomes bombs, electricity becomes power of motion and so forth. Similarly, changes of energy in human beings include hand movements become writing, exercise makes people healthy, studying makes students smart, a smile makes friendly, visit for friendship becomes the path of fortune, and so forth.

When a person does a bad deed, such as corruption, he is actually issuing bad form of energy. Then he consumes the result of corruption and flows into blood and flesh. So, according to the law of conservation of energy, the bad energy will be attached to him with a fixed amount, but it may change the shape, for example, it will return in the form of sickness, accidents, messy households, naughty children and various other disasters. This is in fact also in line with the explanation contained in the Qur>an: Eat among the good sustenance that We have given you, and do not exceed the limit on it, which causes My wrath to fall upon you. And whosoever befallen by My wrath, then he will perish. (Qs. Thaha: 81).

In this verse Allah ta'ala firmly ordered to eat the good and kosher sustenance. And Allah also forbade them from doing beyond the limits of the sustenance, that is, by searching for it and spending it on a haram or forbidden way. If they do so, Allah threatens them with wrath that will destroy him. Ibn Jarir explains the the meaning of the destruction referred to in this verse by saying: "Whosoever has been overwhelmed with My wrath, he is indeed fallen and will surely suffer" (Tafsir Ibn Jarir 18/347). So, think carefully before you take any action, know that there will be short-term and long-term reactions and consequences, because nothing is missing from the consequences.

\section{NOBEL ADVICE THAT STRENGTHENS THE KUALAT TEACHINGS}

Like other tribal societies, the Javanese community has distinctive cultural and life procedures. Uniquely, Javanese ancestors have a smart way in conveying the philosophy of life which is expressed in the form of noble advice. The noble advice is not limited to aspects of life, but also summarizes the hopes, knowledge, and order of community life. The elders (ancestors) leave the noble advice as the ordinance of life, so that the descendants wherever and whenever they are will always remember to maintain good behavior, proper, hold the manners firmly, polite and humble.

When this noble advice is held firmly, it will support the spirit in preventing corrupt behavior within the civil servants. The noble advice also strengthens and supports the kualat teachings, asserts the existence of causation law and teaches the simplicity of life. At least there are 7 (seven) elements of noble advice which are relevant in Javanese society, such as:

\section{Aja keminter mundak keblinger, aja cidra mundak cilaka}

"Do not feel the smartest so as not to be misdirected, do not cheat so as not to harm". This noble advice reminds everyone that feeling the smartest will only bear misfortune. Besides, it also reminds everyone not to commit fraudulent behavior, because fraudulent behavior will also lead to misfortune. When associated with corruption, it is obvious that corruption is part of fraudulent behavior that will bring harm. 


\section{Sopo Nandur bakal Ngunduh/Ngunduh} Wohing Pakerti

"Those who plant will harvest / harvest the fruit of behavior". This noble acvice is in line with the causation law that everybody will get the consequences of his own behavior. This noble advice reminds us to always race to plant goodness whenever and wherever we are. And vice versa, we must be careful in acting, because every evil will get the evil.

3. Sopo sing kelangan bakal diparingi, sopo sing nyolong bakal kelangan "Those who lose will be given, those who steal will lose". This noble advice has a very deep impression in life. This means that our ancestors had long understood that anyone who stole would actually make him lose something. Through the noble advice, our ancestors advised us on justice that God is the fairest judge.

\section{Becik ketitik Olo Ketoro}

"Good deeds will be recognized and bad deeds will be seen clearly". Though covered, bad deeds will eventually be uncovered. And good deeds will eventually be recognized and get the reward. This noble advice at least gives us two counsels. First, do goodness, because there is nothing in vain from our good deeds. Second, never cheat others, because in the end the bad deed will be uncovered.

\section{Nrimo Ing Pandum}

"Receive all gifts sincerely". It means that people must be sincerely willing to accept the results according to what becoming his part. The noble advice contains a profound meaning that shows the attitude of honesty, sincerity, happy to work and the unwilling to commit corruption. We are taught to be willing to accept sincerely everything that happens in our lives. This advice teaches us not to become greedy and want the property of others.
6. Ojo Adigang, Adigung, Adiguno

"Do not boast the power, authority, intelligence". This expression is very popular in Javanese society. This noble advice reminds us not to be arrogant and not to underestimate others by our power. Adigang, adigung, adiguna are forms of arrogance that will make people around us uncomfortable and eventually ruin our lives.

\section{Sopo Sing Salah Bakal Seleh}

"Those who do evil will lose." In supporting the kualat teaching, this noble advice also gives us the understanding that those who do bad deeds will eventually lose. Bad deeds and good deeds will actually return to the doers. Through this advice, we should never think that the act of corruption will be uncovered.

\section{INSTILLING KUALAT TEACHINGS WITHIN CIVIL SERVANTS THROUGH LEADERSHIP EDUCATION AND TRAINING (DIKLATPIM) VI}

Education and training are an integral component of Human Resource (HR) Management. Law Number 05 Year 2014 on State Civil Apparatus regulates the development of employee competency through education and training. Article 70 states that each State Civil Apparatus, including civil servant, has the right and opportunity to develop such competence through education and training. One of the efforts in establishing leadership capability in Government bureaucracy is through Leadership Education and Training (Diklatpim). One of the trainings held for the purpose of the formation and development of leadership is the Leadership Education and Training (Diklatpim) IV, ie the level of leadership training which is aimed at the officials of Echelon IV.

Furthermore, as a contribution in the prevention of corrupt behavior among civil servants, the author gives the idea of the need for the internalization of the kualat teachings 
as one of the material content of Diklatpim IV. The author presents this material content to the leadership training because the leadership is a crucial element in government bureaucracy. The behavior and success of an organization are strongly influenced by the quality of the leaders in each agency. The author chooses the material content in Diklatpim IV with the consideration that the training is the first level in the leadership training before continuing to the higher levels of leadership training. The author sees that this understanding of kualat teachings must have been possessed from the beginning by the holders of office in the Government. In accordance with the Regulation of the Head of State Administration Agency (LAN) Number 13 of 2013 on Guidelines for the Implementation of Leadership Training and Education (Diklatpim) IV, that the competencies built on Diklatpim IV are character and integrity attitude in accordance with legislation and ability to uphold public ethics, adherence to values, norms, morality and being responsible in leading hisor her institutional units.

According to the Indonesian Dictionary, internalization is the appreciation of a teaching, doctrine, or value so that it becomes a belief and awareness of the truth or value embodied in attitudes and behavior. Through the internalization of kualat teachings, the participants of the leadership training are expected to be the leaders of change, role model for members of the organization with an attitude as a leader with integrity, dare to take decisions with all risks, and care about the situation and condition of internal and external organizations that are constantly changing.

As the supporting data for the internalization of kualat teaching, the author has conducted a survey of 38 people (all participants) of Diklatpim IV Class 27 at the Ministry of Maritime and Fisheries Apparatus Training Center, with 3 (three) questions related to their views on the kualat teachings. The first question, Do you know what kualat is? Question 2, Do you believe in kualat?, and Question 3, Do you make kualat teaching as a consideration in decision-making or policymaking? Results of respondents' answers to these questions can be seen in the graph as follows

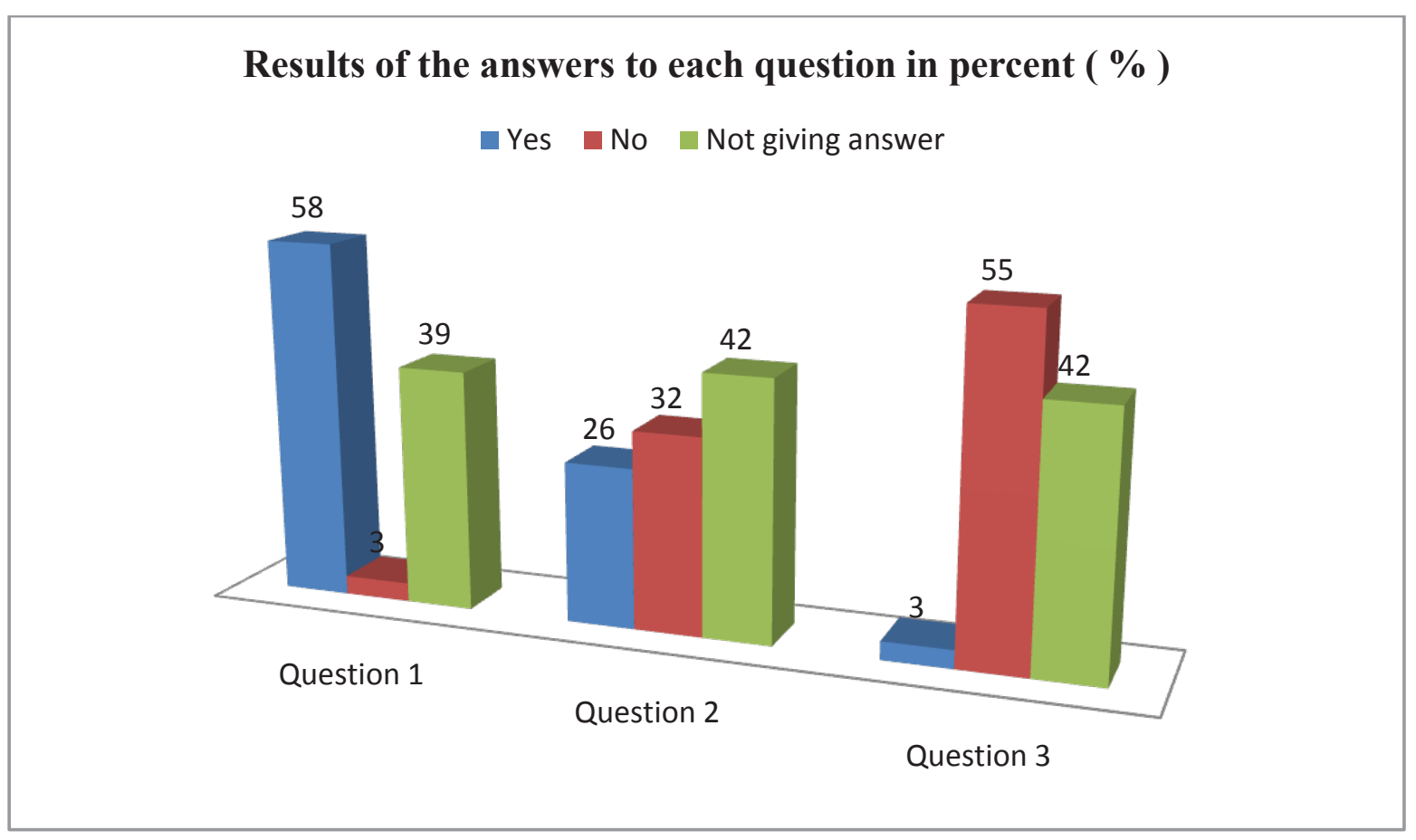


For question 1, it shows that $58 \%$ of the participants say Yes, 3\% say No and 39\% are unwilling to answer. For question 2, the result shows that $26 \%$ say Yes, $32 \%$ say No, and $42 \%$ are unwilling to answer. Then for question 3 , the result shows that 3\% say Yes, 55\% say No and $42 \%$ are unwilling to answer. From the results of the answer, it is known that, in fact, most of the respondents know what kualat is, but of the 38 participants, only $26 \%$ who believe. The most critical point is on the answer to the third question, in which of all respondents, only $3 \%$ who make their knowledge and belief in kualat as a consideration in decision-making. From the results of the survey, it can be seen that that corrupt behavior among civil servants is still quite high. This is evidenced by the low implementation of knowledge and beliefs on the kualat teachings as a consideration in decision-making or policy-making.

\section{CONCLUSION AND SUGGESTION}

Based on the above description, it can be concluded that the problem of corruption is really a serious problem that must be overcome. Efforts to prevent and eradicate corruption need to be done comprehensively across aspects and reviews. Various approaches should be done ranging from legal aspect, religious aspect, social aspect, to cultural aspect. Of the various approaches, it is the cultural approach that has not been done optimally. Yet, as Edward T. Hall points out that it is cultural approach that has significant effect on behavior. Culture is defined as a total complexity of all human thoughts, feelings, and actions. Such a coercive cultural image will equip its members with appropriate codes of conduct. Therefore, to overcome various national problems, including corrupt behavior among civil servants, it is necessary to revitalize the national culture aspect. The Indonesian people need to return to identity as a nation, and this can only be done by rediscovering the growing roots of culture in society.
Furthermore, the author as Widyaiswara (Civil Servant who is appointed as functional officer by authorized officers with duties, responsibilities, authority to educate, teach, and / or train Civil Servants at government education and training institutions) in the Training Center for Apparatus of Ministry of Marine and Fisheries herewith conveys the idea of the need for the internalization of kualat teachings within civil servants through the material content of Leadership Education and Training (Diklatpin) IV. This is reinforced from the survey results to the participants of Diklatpim IV of class 27 in the Balai Diklat Aparatur Sukamandi, in which the kualat teaching has faded, especially in its implementation in every decision-making. The author presents this idea as the basis of consideration of policy-making for the parties involved directly or indirectly in the development of Diklatpim IV. The author conveys this input especially to the State Administration of the Republic of Indonesia in accordance with Law No. 5 of 2014 on State Civil Apparatus, that State Administration Agency (LAN) is a non-ministerial Government Agency authorized to conduct assessment, education, and training for civil servants.

\section{REFERENCES}

Andi Hamzah.,Pemberantasan Korupsimelalui Hukum Pidana Nasional dan Internasional,Depok: Rajawali Pers, 2015

Komisi Pemberantasan Korupsi.,Memahami untuk Membasi Buku Saku untuk Memahami Tindak Pidana Korupsi, Jakarta: KPK, 2006

Agus Dwiyanto, dkk.,Reformasi Birokrasi Publik di Indonesia, Yogyakarta: UGM Pers, 2002

Djoko Prakoso., Pembinaan Pegawai Negeri Sipil, Jakarta: Rineka Cipta, 1991

Frans Magnis Suseno.,Etika Jawa: Sebuah Analisa Falsafi tentang Kebijaksanaan 
Hidup Jawa, Jakarta: Penerbit PT Gramedia, 1984

Soedjatmoko., Etika Pembebasan Pilihan Karangan tentang Agama Kebudayaan Sejarah Ilmu Pengetahuan, Jakarta:LP3ES, 1984

Koentjaraningrat.,Pengantar Antropologi, Jakarta: Rineka Cipta

Prof. Dr. M. Bambang Pranowo.,Memahami Islam Jawa: Kajian Agama/Sosial/ Demokrasi, Ciputat, Jakarta Selatan Indonesia: Pustaka Alvabet, 2009

Darusuprapta.,Arti dan Nilai Babad dalam Kebudayaan Jawa, Yogyakarta: Javanologi, 1985

Edi Sedyawati, dkk.,Pedoman Penanaman Budi Pekerti Luhur, Jakarta: Balai Pustaka, 1999

Haryadi, Suwardi, Mulyana.,Nilai budi pekerti dalam ungkapan tradisional Jawa, Yogyakarta:Lembaga Penelitian Universitas Negeri Yogyakarta, 2000
Koentjaraningrat.,Kebudayaan Jawa,Jakarta: Balai Pustaka, 1984

Magnis-Suseno, F. 1984.,Etika Jawa: Sebuah analisa falsafi tentang kebijaksanaan hidup Jawa, Jakarta:Gramedia, 1984

Ihromi, T.O., Pokok-pokok Antropologi Budaya, Jakarta: Yayasan Obor Indonesia, 1996.

\section{Legislations:}

Law Number 05 of 2014 on State Civil Apparatus

Law Number 30 of 2002 concerning the Corruption Eradication Commission (KPK)

Regulation of the Head of State Administration Institution (LAN) No. 13 of 2013 on Guidelines for Implementing Leadership Education and Training (DIKLATPIM) IV 
Afnan Fuadi : Internalization of 'kualat' teaching as an attempt to prevent corrupt .....

Page 1-9 